\title{
LXIV. On the measurement (by trigonometry) of the heights of the principal hills of Wensleydale, Yorkshire
}

\section{John Nixon Esq.}

To cite this article: John Nixon Esq. (1829) LXIV. On the measurement (by trigonometry) of the heights of the principal hills of Wensleydale, Yorkshire , Philosophical Magazine Series 2, 5:30, 431-441, DOI: 10.1080/14786442908675039

To link to this article: http://dx.doi.org/10.1080/14786442908675039

曲 Published online: 10 Jul 2009.

Submit your article to this journal $[\pi$

Џll Article views: 2

Q View related articles $\sqsubset$ 
boring has been carried 250 feet below the surface, but with occasional changes in the strata. What these were I was unable to learn; Mr. Merritt, the proprietor, being absent at the time. While the water of the creek, only a few feet off, is quite sweet, that of the spring is very salt, and copious. It is sometimes very red. Fifty gallons make a bushel of salt, which is very white, and in small and thin irregular tables; 3640 bushels are made in a year, worth on the spot about 550l. sterling.

The Parallel Ridge, a mountain overlooking this flat, is composed of the same materials as the chasm of the River Niagara, which have already been declared to be, successively, from below, saliferous sandstone, ferriferous sandstone and slate, calciferous slate, and geodiferous limestone rock. I therefore refer the reader to my account of that river for any additional particulars respecting these strata that may occur in that ridge.

J. J. BigsBy.

LXIV. On the Measurement (by Trigonometry) of the Heights of the principal Hills of Wensleydale, Yorkshire. By JoHN Nixon, Esq.

[Concluded from page 362.$]$

SOME time previous to the commencement of the survey, $D$ the great levels of the horizon-sector had been fitted up with scales divided into equal parts (of about two seconds each), numbered from the end of the scale the nearest to the eyepiece of the telescope progressively to the one next to the object-glass.

The zero of each index (carrying the levels) being placed exactly in a line with that of its graduated arch (fixed to the telescope), on which it moves, the following method was adopted in order to ascertain at what two divisions of its scale the bubble of each level would remain stationary on reversing the telescope within its Ys.

The sector, placed in the shade on a perfectly steady support (such as a rock or well-built wall), having acquired the temperature of the ambient air, the inclination of the telescope was varied until the bubble of either level; for instance, that of the right index, moved to about the middle of its scale. After a lapse of a few minutes, the divisions of the scale coincident with the two extremities of the bubble were read off and registered. In the second place, the telescope was inverted within its $Y s$, and the corresponding position of the bubble of the left-index level (now uppermost) read off. Lastly, the telescope 


\section{$4.32 \mathrm{Mr}$. Nixon on the Measurement (by Trigonometry) of the}

telescope being taken out of its $\mathrm{Y}_{\mathrm{s}}$, and replaced reversed in position, the bubble of the left-index level, and afterwards, on inverting the telescope, that of the right-index level, were read off as before. The reversing point of the middle of the bubble of either level being evidently equal to one-fourth of the sum of the readings of the position of its ends in the direct and reversed positions of the telescope, two marks were made with a camel-hair pencil dipped in white paint on the tube of each level, one on each side of, and equidistant from the reversing point by half the length of the bubble.

The sector had been transported in the course of the survey in vehicles of every description over the roughest roads imaginable; yet the great levels, as will be evident from the subjoined statement of the position of their reversing points at the several stations, had retained their first adjustments to the accuracy of a second or two.

\begin{tabular}{|c|c|c|c|c|}
\hline \multirow{4}{*}{ Reversing point at } & & ght Inder & Left Index. & Mean \\
\hline & it Bear's Head. & $67^{\circ}$ & $74^{\circ}$ & $70^{\circ} \cdot 5$ \\
\hline & Shunnor Fell ... & 66 & 72 & 69 \\
\hline & Bakestone Edge. & $62 \cdot 5$ & 76 & 69 \\
\hline & Penhill $\ldots \ldots \ldots$ & 65 & $76 \cdot 5$ & 71 \\
\hline - (July 9th) & Settronside..... & $61 \cdot 5$ & $76 \cdot 5$ & 69 \\
\hline - (July 10th) & $\ldots \ldots$ & $65 \cdot 5$ & 75 & 70 \\
\hline & & & Mean & $70^{\circ}$ \\
\hline
\end{tabular}

Heretofore the vertical angle could not be measured until the ends of the bubble were made to coincide exactly with the reversing marks; but on the addition of scales to the levels, the angle read off could be corrected for any slight deviation of the bubble from its marks, by noting the contemporary position of the ends of the bubble. To understand the nature of this correction, it is to be observed, that when the telescope is pointed at an elevated object, and the index moved until the bubble of its level comes to rest at its marks, the zero of the index will be lower than that of the graduated arch (fixed to the telescope) by the arc of elevation. Consequently, on subsequently elevating the index in a slight degree, the two zeros will be brought nearer to each other; the displaced bubble, advancing in the direction of the object-glass, will come to rest with its middle point opposite a number in the scale exceeding that of the reversing point; and the angle of elevation now read off on the graduated arc, will be in defect by the angular displacement of the bubble. Hence the registered angles of elevation will require correcting by the difference in seconds of the half-sum of the readings of the position of the ends of the bubble and that of the reversing point; additive or subtractive 
subtractive according as the half-sum exceeds or falls short of the reversing point. For angles of depression the correction is to be applied with the contrary signs. The value of one division (of forty to the inch) of the right-index level is $1^{11 \cdot 91 \text {; }}$ that of the left-index level $2^{\prime \prime} \cdot 12$.

On calculating the cylindrical error of the sector from measurements by the scales, substituted for those previously obtained by the divided arcs, its amount was determined to be $20^{\prime \prime}$, instead of $11^{\prime \prime}$ as last stated; the discrepancy arising principally from a gross error existing in the formula*.

The ground about the station at Penhill being an almost impassable bog destitute of rocks, the tripod of the theodolite, having a firm board screwed to it, was fixed on the turf-mound already described. From the elastic nature of the materials of the mound, the slightest change in the position of the observer displaced the bubble of the level several minutes, and threatened to render the accurate measurement of the angles utterly impracticable. Fortunately, after abandoning various plans of overcoming the difficulty, the following method of conducting the observations was tried and found to succeed extremely well: An approximate measurement being effected, the weight of the body was thrown for a moment on one foot, and a light stone, placed on the board, moved gradually in the proper direction until the line of collimation pointed exactly at the base of the signal. Averting the head as slightly as possible, the position of the bubble was then read off at one rapid glance, and the eye replaced as instantaneouslyat the telescope, to ascertain that its direction remained unvaried. Tedious and difficult as was the method in execution, it was gratifying to find that the results equalled in accuracy the measurements effected in the usual way at Settronside with the sector placed on a wall, or supported, as at the other stations, on firm piles of stones surmounted by a heavy flag.

The observed refractions, with their deviations from the mean value, about 1-17th, are stated below:

Arc. Refr. Deviat.

Shunnor Fell and Bakestone Edge $4^{\prime} 19^{\prime \prime}-17^{\prime \prime}-32^{\prime \prime}$

Bear's Head and Whaw Fell

Bakestone Edge and Bear's Head

Penhill and Settronside

4. $36+19+3$

Bear's Head and Shunnor Fell

Settronside and Bear's Head

$5619+1$

$539 \quad 17: 5-2.5$

$551 \quad 12-9$

Shunnor Fell and Knoutberry Hill

$\begin{array}{lll}620 & 27 & +5\end{array}$

$621 \quad 16-6$

* Some time in the course of the present year I hope to be able to furnish your readers with a complete treatise "On the constant Error of Collimation of a Telescopic Level."

N.S. Vol. 5. No. 30. June 1829.

$3 \mathrm{~K}$

Dod 
434 Mr. Nixon on the Measurement (by Trigonometry) of the

\begin{tabular}{|c|c|c|c|}
\hline Dod Fell and Shunnor Fell & $\begin{array}{l}\text { Arc. } \\
6^{\prime} 55^{\prime \prime}\end{array}$ & $\begin{array}{l}\text { Refr. } \\
19^{\prime \prime}\end{array}$ & $\begin{array}{l}\text { Deviat. } \\
-5^{\prime \prime}\end{array}$ \\
\hline Penhill and Bakestone Edge & 740 & 26 & -1 \\
\hline Bakestone Edge and Settronside & 847 & $4: 1$ & +10 \\
\hline Bear's Head and Penhill & 849 & $25 \cdot 5$ & -5.5 \\
\hline Penhill and Dod Fell & 1036 & 49 & +12 \\
\hline Shunnor Fell and Settron Fell & 1138 & 37 & -4 \\
\hline Penhill and Pen-y-gent & 1240 & 40 & -5 \\
\hline $\begin{array}{l}\text { rejecting the first) } \\
\text { Mean refraction }\end{array}$ & 4050 & 48 & \\
\hline
\end{tabular}

The registers of the measurements by the horizon-sector will require explanation. The first column contains the name of the hill of which the ground, unless otherwise stated, had been observed; the second, the mean of the readings by the two indices of the elevation or depression, each corrected for the constant error of the instrument and the deviation of the bubble from its reversing point; the third, the difference of level of the cam at Penhill, the walls at Settronside and Pen$y$-gent, and the ground at the other stations and the summit or other given part of the observed hill; the latter being higher or lower than the former according as the difference is marked H or L.-The last column, given merely as a test of the goodness of the observations, exhibits the difference between the error of collimation of each (pair of) observations, and the mean error of the whole $\dagger$.

\section{At Settronside Wall.}

The measurements marked* were made July 9 th, 1828 ; a cold but clear day accompanied by a tremendous wind; the others were made on the following day, of which the earlier part proved remarkably bright and elear, but was succeeded by partial mists.

Height of the eye above the wall 0.5 feet.

\begin{tabular}{|c|c|c|c|}
\hline *Penhill, Cam top & $51^{\prime} 22^{\prime \prime}$ & depr. & $\begin{array}{l}\text { Feet. } \\
\text {. - }\end{array}$ \\
\hline *Little Whernside & 5036 & & $\ldots$ \\
\hline & $\begin{array}{ll}50 & 24 \\
65 & 38\end{array}$ & & $\begin{array}{c}318 \cdot 1 \\
\ldots .\end{array}$ \\
\hline & $\begin{array}{ll}65 & 30 \\
50 & 46\end{array}$ & & $\begin{array}{l}754.3 \\
518 \cdot 8\end{array}$ \\
\hline thwaite Moor & 3735 & & $195 \cdot 2$ \\
\hline & 2822 & & $287 \cdot 3$ \\
\hline Lo & 925 & & $87 \cdot 9$ \\
\hline
\end{tabular}

$\dagger$ In the calculations the refraction has been considered to be without exception 1-17th of the contained arc.

Bakestone 
Heights of the principal Hills of Wensleydale, Yorkshire. 4.35

Bakestone Edge

Caldberg Moort

Feet.

Whitfield Hill, Wall top $54,10-\quad 948 \cdot 3 \quad 2$

Wasset Fell

Stake Fell

*Great Whernside

Ingleborough

Shunnor Fell

$28^{\prime} 16^{\prime \prime}$ depr. 379.3 L. $4^{\prime \prime}$

$67 \quad 0 \quad 946.72$

$2^{\circ} 1128-429 \cdot 7 \quad 5$

$12225-463 \cdot 2 \quad 0$

$049-\ldots 0$

$12-4 \cdot 1 \mathrm{H} .6$

$28-68.3 \quad 3$

$256-46 \cdot 16$

At the Bear's Head.

June 26, 1828. A cold, clear, blustry afternoon. Height of eye 4 feet.

Ten End

Whaw Fell

Bakestone Edge

High Fleak

Pickington Ridge

WhitfieldHill, Wall top

Addlebrough

Penhill, Cam top

Harlen Fell

Stake Fell

Wasset Fell

Brownhaw

Little Whernside

Great Haw

Shunnor Fell

Ingleborough

Lovely Seat

The Sayls

Pillar Hill

Swarth Fell

Knoutberry Hill

Dod Fell

Yockenthwaite Moor

Settronside, Wall top

Wildboar Fell

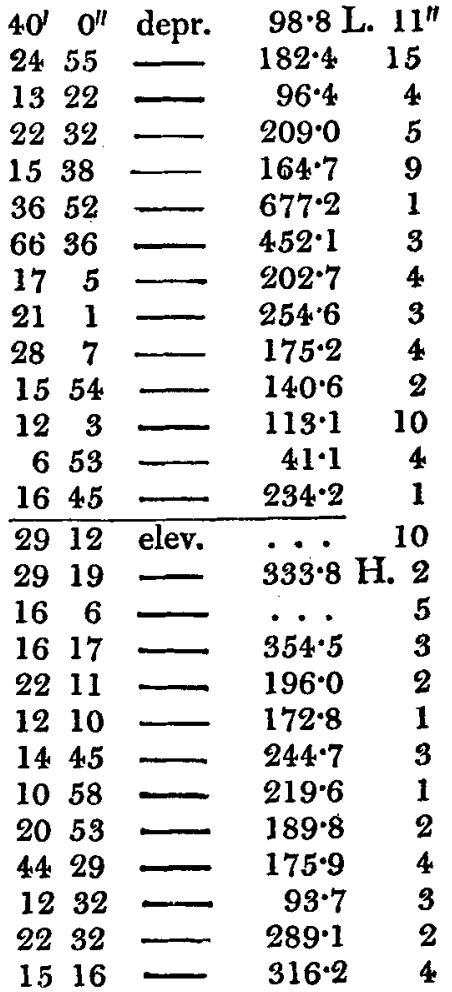

† It is very probable that a rock had been mistaken for the signal. 
436 Mr. Nixon on the Measurement (by Trigonometry) of the

\section{At Shunnor Fell.}

June 27, 1828. Excessively sultry, calm and hazy.

\begin{tabular}{|c|c|c|c|c|}
\hline $\mathrm{He}$ & f eye 4 & & Feet. & \\
\hline Pillar Hill & $23^{\prime} 56^{\prime \prime}$ & depr. & $91 \cdot 0 \mathrm{~L}$ & - $6^{\prime \prime}$ \\
\hline The & 4313 & & $161 \cdot 0$ & 14 \\
\hline Swarth Fell & 1536 & & $115^{\circ} 6$ & 10 \\
\hline Wildboar Fell & 5. 34 & & $25 \cdot 8$ & 5 \\
\hline Lovely Seat & 3931 & & $135 \cdot 2$ & 6 \\
\hline Bakestone Edge & $58 \quad 53$ & & - & 7 \\
\hline & $\begin{array}{l}3040 \\
3529\end{array}$ & & $\begin{array}{l}4311^{8} \\
396.0\end{array}$ & 12 \\
\hline all & 741 & & $48 \cdot 5$ & 10 \\
\hline Ridge & $39 \quad 12$ & - & $501 \cdot 6$ & 9 \\
\hline rod & 1819 & & $159 \cdot 6$ & 7 \\
\hline ry Hill & 1556 & & 14.3 .5 & 1 \\
\hline & 1637 & & $162 \cdot 3$ & 1 \\
\hline I & 54 & & 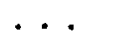 & 6 \\
\hline
\end{tabular}

At Bakestone Edge.

June 30,1828 . Very hazy, with a hot sun and a cloudless sky; frosty in the evening.-Height of eye 4.5 feet.

Ten End

Stake Fell

Pickington Ridge

High Fleak

Penhill, Cam top

Little Whernside

Bear's Head

Lovely, Seat

Shunnor Fell

Water Crag

Settronside, Wall top

Yockenthwaite Moor

Great Whernside
Feet.

\begin{tabular}{|c|c|c|c|}
\hline $3^{\prime} 30^{\prime \prime}$ & depr. & $5 \cdot 0 \mathrm{~L}$ & . $3^{\prime \prime}$ \\
\hline 1055 & & $79 \cdot 2$ & 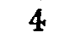 \\
\hline 1220 & & 66.9 & 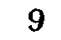 \\
\hline 3956 & & 114.2 & \\
\hline 1127 & & $105 \cdot 5$ & 6 \\
\hline 152 & - & $59 \cdot 1 \mathrm{H}$. & .6 \\
\hline 757 & elev. & $96 \cdot 8$ & 4 \\
\hline 4455 & & $293 \cdot 2$ & i \\
\hline $\begin{array}{ll}53 & 9\end{array}$ & & $4.26 \cdot 1$ & 5 \\
\hline 2510 & & $265 \cdot 1$ & 4 \\
\hline 2033 & & $384 \cdot 5$ & 3 \\
\hline 1051 & & $188 \cdot \varepsilon$ & \\
\hline 1242 & & 385.4 & \\
\hline
\end{tabular}

At Penhill Cam.

July 1, 1828. A sultry, misty morning succeeded by a clear but rather blustry evening.

Height of the eye above the Cam top 4 feet.

Harlen Fell

Great Haw
Feet.

$$
\begin{array}{ccccc}
30^{\prime} & 40^{\prime \prime} & \text { depr. } & \begin{array}{c}
\text { Feet. } \\
61.9
\end{array} \text { L. } 2^{\prime \prime} \\
31 \cdot 0 & 36 & - & 0
\end{array}
$$

+ Miscalled Cotterfell in the last survey. 
Heights of the principal Hills of Wensleydale, Yorkshire. 437

Addlebrough

High Fleak

Caldberg Moor

Stake Fell

Settronside, Wall top

Great Whernside

Wasset Fell

Brown Haw

Little Whernside

Bear's Head

Pickington Ridge

Bakestone Edge

Yockenthwaite Moor

Lovely Seat

Shunnor Fell

Dod Fell

Pen-y-gent, Wall top

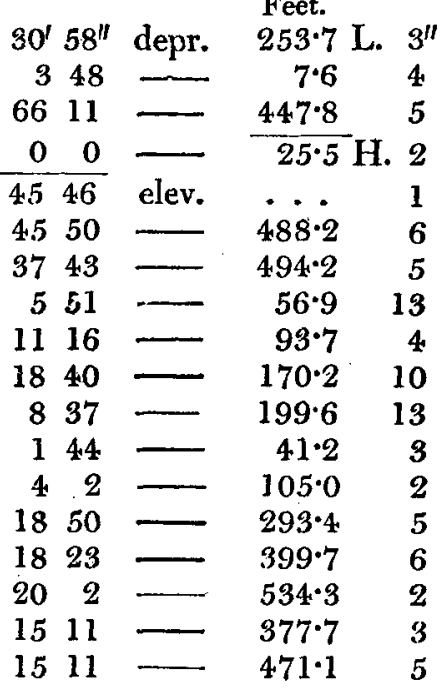

At Ingleborough.

June 14th and 18th, 1822.-Height of eye 4 feet.

Great Whernside

Shunnor Fell

$9^{\prime} 0^{\prime \prime}$ depr. $65 \cdot 6 \mathrm{~L}$.

$710-24.4$

At Whernside.

July 4th and 6th, 1827:- Height of eye 4 feet.

Feet.

Ingleborough

Shunnor Fell

$8 ! 47^{\prime \prime}$ depr. $\quad 42 \cdot 6 \mathrm{~L}$.

$827-67.3$

At Knoutberry Hill†.

July 5th, 1827.-Height of eye 4 feet.

Ingleborough

Shunnor Fell

Great Whernside

Feet.

167. $\mathrm{H}$.

$\begin{array}{lll}92 & 34^{\prime \prime} \text { elev. } \\ 9 & 25 & 167.3\end{array}$

155 depr. 100.7

At Pen-y-gent Wall.

July 11th, 1827.-Height of the eye above the wall 9 inches.

Ingleborough

Shunnor Fell

Great Whernside

Penhill, Cam top

Feet.

$7^{\prime} 8^{\prime \prime}$ elev. 89:3 H.

252 depr. $65 \cdot 1$

$223-24: 2$

† In the last survey for Noughtberry Hill read Knoutberry Hill. 
$438 \mathrm{Mr}$. Nixon on the Measurement (by Trigonometry) of the

At Dod Fell.

August 25th, 1827.-Height of eye 4 feet.

Ingleborough $\quad 950$ elev. $180 \% \mathrm{H}$.

Shunnor Fell $\quad 941-160.3$

Great Whernside $\quad 140-118 \%$

At Whaw Fell.

September 15th, 1824, and March 29th, 1825.

Height of eye 3.5 feet. Feet.

Ingleborough

Shunnor Fell

$46^{\prime} 17^{\prime \prime}$ elev. $536 \cdot 3 \mathrm{H}$.

Bear's Head

$3529-512 \cdot 0$

$1957-183 \cdot 1$

At Great Whernside.

April 15th, 1822.

Height of the eye above the loftiest rock 1 foot.

Swarth Fell $+\quad 10^{\prime} 7^{\prime \prime}$ depr. $\begin{gathered}\text { Feet. } \\ 70.5\end{gathered}$ L.

Penhill Beacon $\quad 5019-635.4$

Calculation of the mean Differences of Level and Heights of the Stations.

Ingleborough above Great Whernside. Ingleborough above Strunnor Fell.

$\ddot{\omega}$ Ingleborough

Settronside

Knoutberry Hill

Pen-y-gent

cis Dod Fell

Corrected mean

Height of Ingleborough

Great Whernside

Shunnor Fell above Great Whernside.

๘. $\left\{\begin{array}{l}\text { Settronside } \\ \text { Bakestone Edge } \\ \text { Penhill } \\ \text { Ingleborough } \\ \text { I. } \\ \text { Knoutberry Hill } \\ \text { Pen-y-gent } \\ \text { Dod Fell }\end{array}\right.$

Corrected mean

Height of Great Whernside Shunnor Fell

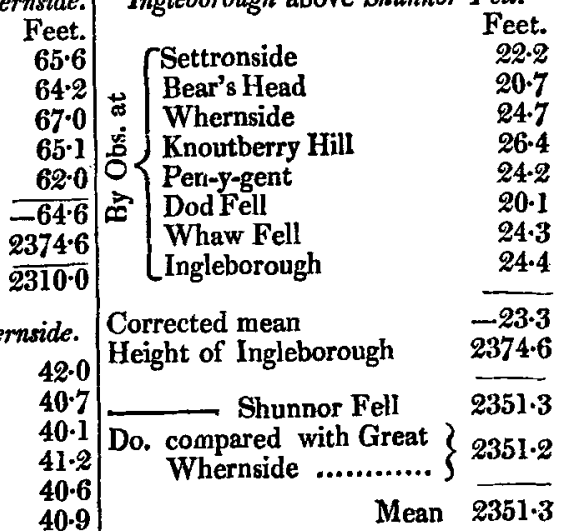

+ The observation was made six years previous to the erection of the signal. 
Heights of the principal Hills of Wensleydale, Yorkshire. 4.39

Shunnor Fell above SettronsideWall. Great Whernside above Bear's Head.

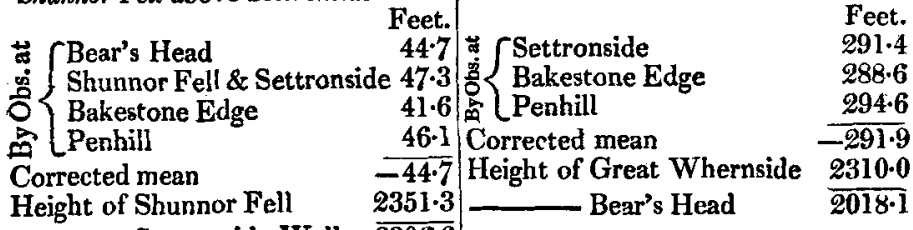

Settronside Wall $\overline{2306 \cdot 6}$

Ingleborough above SettronsideWall.

E Settronside $68 \cdot 3$

है Bear's Head 65.4

ShunnorFell \& Ingleborough72.9

Corrected mean

$-68 \cdot 6$

Height of Ingleborough $\quad \mathbf{2 3 7 4 . 6}$

- Settronside Wall $\overline{\mathbf{2 3 0 6} \cdot 0}$

Great Whernside above Settronside Wall.

F Settronside

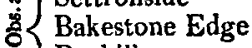

Penhill

Corrected mean

Height of Great Whernside

Settronside Wall $\overline{\mathbf{2 3 0 5} \cdot 8}$

Do. compared with Inglebro' $2306 \cdot 0$ ShunnorFell2306.6

Mean $\overline{2306 \cdot 1}$

Height of Wall above ground $-1 \cdot 6$

- Summit of Settronside $\overline{\mathbf{2 3 0 4} \cdot \overline{5}}$

Ingleborough above Bear's Head.

$\vec{z}$ CSettronside

s. Bear's Head

О Shunnor Fell \& Inglebro' 361.3

(Whaw Fell

Corrected mean

Height of Ingleborough

353.2

Bear's Head

$\overline{355 \cdot 4}$
$2374 \cdot 6$
$\overline{2019 \cdot 2}$

Settronside above Bear's Head.

*. Settronside \& Bear's Head 288.2

Shunnor Fell 288.4

Bakestone Edge 287.7

Lenhill 288.6

Corrected mean $\overline{-288.2}$

Height of Settronside Wall $2306 \cdot 1$

Do. compar's Head

Do. compared with Great
Whernside 2018.1

Shunnor Fell 2019.3

$\cdot 1$

0.9

$6 \cdot 0$

Ingleborough above Penkill Cam.

๘े Settronside $\mathbf{5 5 7 \cdot 3}$

i. Bear's Head $\quad \mathbf{5 5 7 \cdot 2}$

? Pen-y-gent $\quad \mathbf{5 6 3 . 8}$

Dod Fell 550.9

Corrected mean $\quad-\mathbf{5 5 6 . 8}$

Height of Ingleborough $\quad \mathbf{2 3 7 4 . 6}$

Penhill Cam $\quad \overline{\mathbf{1 8 1 7 \cdot 8}}$

Shunnor Fell above Penhill Cam.

4 CSettronside $535 \cdot 1$

\& Bear's Head $\mathbf{5 3 6 . 5}$

(8) Bakestone Edge $\quad 531 \cdot 6$

\{ $\begin{cases}\text { Penhill } & \mathbf{5 3 4 . 3}\end{cases}$

> Pen-y-gent $\quad \mathbf{5 3 9 . 6}$

Dod Fell $\quad \mathbf{5 3 0 . 8}$

Corrected mean $\quad \overline{\mathbf{5 3 4 \cdot 6}}$

Height of Shunnor Fell 2351.3 Penhill Cam $\overline{\mathbf{1 8 1 6 \cdot 7}}$

Shunnor Fell above Bear's Head. Great Whernside above Penhill Cam.

$\triangle$ Settronside 333.4

Bear'sHead \&ShunnorFell 335.3

$\triangle$ Settronside 493.1

335.3 Bakestone Edge $\quad 490 \cdot 9$

Bakestone Edge 329.3

Penhill 334.7

की Whaw Fell

328.9

\{ Penhill

Pen-y-gent

$494 \cdot 2$

498.7

488.9

Corrected mean

$\overline{\mathbf{3 3 2} 0}$ Corrected mean

$-4 \overline{92.9}$

Height of Shunnor Fell

$2351 \cdot 3$

Height of Great Whernside

$2310 \cdot 0$

Bear's Head

$\overline{\mathbf{2 0 1 9 \cdot 3}}$

1817.1 


\section{$440 \mathrm{Mr}$. Nixon on the Measurement (by Trigonometry) of the}

Settronside Wall above Penhill Cam. Shunnor Fell above Bakestone Fdge.

\begin{tabular}{lr} 
& Feet. \\
Penhill and Settronside & $\mathbf{4 8 8 \cdot 6}$ \\
Bear's Head & $491 \cdot 8$ \\
Bakestone Edge & $\mathbf{4 9 0 \cdot 0}$ \\
Corrected mean & $-\overline{489 \cdot 8}$ \\
Height of Settronside Wall & $\mathbf{2 3 0 6 \cdot 1}$ \\
\hline
\end{tabular}

Bear's Head above Penhill Cam.

S Settronside

$201 \cdot 7$

Bear's Head and Penhill

Bakestone Edge

Corrected mean

Height of Bear's Head

$201 \cdot 1$.

$\underline{202 \cdot 3}$

$2018 \cdot 6$

$\overline{1816 \cdot 9}$

Do. compared with Inglebro' $1817 \cdot 8$ $\mathrm{G}^{\mathrm{t}}$ Whernside 1817.1

Shunnor Fell 1816.7

Settronside 1816-3

Mean $\overline{181 \overline{7} \cdot 0}$

The top of the Cam is about level with the lighest point of Penhill.

Ingleborough above Bakestone Edge.

ज Settronside

: Bear's Head

LShunnor Fell and Inglebro' 456.2

Corrected mean

Height of Ingleborough

\begin{tabular}{c}
$-451 \cdot 1$ \\
$\overline{2374 \cdot 6}$ \\
\hline $192 \overline{3.5}$
\end{tabular}

- Bakestone Edge

Great Whernside above Bakestone

Edge.

离 $\left\{\begin{array}{l}\text { Settronside } \\ \text { Bakestone Edge } \\ \text { Penhill }\end{array}\right.$

Corrected mean

Height of $\mathrm{G}^{ \pm}$Whernside

Bakestone Edge

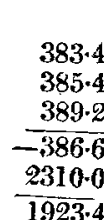

$\begin{array}{r}383 \cdot 4 \\ 385 \cdot 4 \\ 389 \cdot 2 \\ \hline-386 \cdot 6 \\ \hline 2310 \cdot 0 \\ \hline 1923 \cdot 4\end{array}$
Feet.

42.54

$430 \cdot 2$

$429 \cdot 0$

$429 \cdot 3$

$-\overline{428.9}$

$2351 \cdot 3$

$\longdiv { 1 9 2 2 4 }$

Bakestone Edge above Penhill Cam.

SSettronside 109.7

Bear's Head 106-3

$109 \cdot 7$
$106 \cdot 3$
$105 \cdot 2$

Corrected mean $\quad+\overline{107 \cdot 0}$

$\begin{array}{lr}\text { Height of Penhill Cam } & 1817.0 \\ \text { Bakestone Edge } & 1924.0\end{array}$

Settronside Wall above Bakestone Edge.

Settronside and Bake-
stone Edge

$381 \cdot 9$

$\mathbf{3 8 5} \cdot 5$

Shunnor Fell $\quad \mathbf{3 8 3 - 3}$

(Penhill 383.2

Corrected mean $\overline{\mathbf{3 8 3} \cdot \boldsymbol{6}}$

Height of Settronside Wall $2306 \cdot 1$

19255

Bear's Head above Bakestone Edge.

$\rightarrow$ Settronside $\quad \mathbf{9 2 \cdot 0}$

Edge
Bear's Head \& Bakestone
Ed.6

Shumnor Fell $\quad 94.9$

LPenhill $94 \cdot 6$

Corrected mean $\quad \overline{-95.0}$

Height of Bear's Head $\quad 2018.6$

Bakestone Edge $\overline{19236}$

Do. compared with Penhill $1924 \cdot 0$

$1923 \cdot 5$

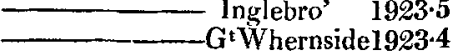

Shunnor 1922.4

Settronside 1922.5

Mean $\overline{1923.2}$

In the following Table are given, for every hill, its height as determined from the stations at the head of the column; the claims to accuracy of the different values of the altitude being considered in the calculation of the mean (contained in the last column), to be reciprocally as the distance of the station to the hill.

Hills. 
Heights of the principal Hills of Wensleydale, Yorkshire. 441

\begin{tabular}{|c|c|c|c|c|c|c|c|}
\hline \multirow[b]{2}{*}{ Hills. } & \multicolumn{6}{|c|}{ STATIONS. } & \multirow[b]{2}{*}{ 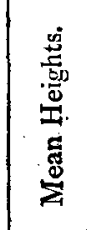 } \\
\hline & 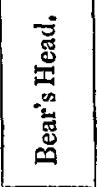 & 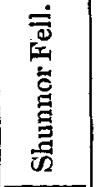 & 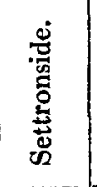 & 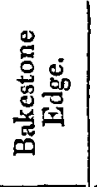 & 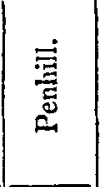 & 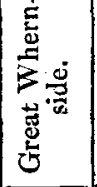 & \\
\hline ar Hill & $\mid 2263 \cdot 3$ & $|2260 \cdot 3|$ & & & & & $\begin{array}{c}\text { Feet. } \\
\text { 2261.0 }\end{array}$ \\
\hline The Sayls & $2191 \cdot 4$ & $2190-3$ & & & & & $2190 \cdot 6$ \\
\hline Swarth Fell .. & 2238.2 & $2235 \cdot 7$ & & & ........... & $\mid \mathscr{2} 239 \cdot 5$ & $2237 \cdot 0$ \\
\hline Lovely Seat . & $2214 \cdot 6$ & $2216 \cdot 1$ & $2218 \cdot 2$ & 2216.4 & $2216 \cdot 7$ & ........... & $.2216 \cdot 1$ \\
\hline High Fleak............. & $1809 \cdot 6$ & & & $1809 \cdot 0$ & $1809 \cdot 4$ & & $1809 \cdot 3$ \\
\hline kington Ridge ... & 1853.9 & $49 \cdot 7$ & ........... & $1856 \cdot 3$ & $1858 \cdot 2$ & & $1855 \cdot 2$ \\
\hline itfield Hill, Wall & $1341 \cdot 4$ & $\cdots$ & $1357 \cdot 8$ & $\cdots \cdot$ & & & $1350 \cdot 5$ \\
\hline $\begin{array}{l}\text { lberg Moor ........ } \\
\text { er Crag.......... }\end{array}$ & & & 1551.8. & $\cdots$ & $1369 \cdot 2$ & & $\mid \begin{array}{ll}1369 \cdot 0 \\
1551 \cdot 8\end{array}$ \\
\hline Haw... & $1784 \cdot 4$ & & $1787 \cdot 3$ & & $1786 \cdot 0$ & & $1786 \cdot 1$ \\
\hline Whernsid & $1977 \cdot 5$ & & $1988 \cdot 0$ & $|1982 \cdot 3|$ & $|1987 \cdot 2|$ & & . $1985 \cdot 4$ \\
\hline nhaw . & $1905 \cdot 5$ & & & & $1910 \cdot 7$ & & . $1909 \cdot 3$ \\
\hline & $1764 \cdot 0$ & & & & $1765 \cdot 1$ & & $1765 \cdot 0$ \\
\hline Penhill Beaco & & & & & & $1674 \cdot 6$ & $1674 \cdot 6$ \\
\hline Wasset Fell :- & 1878.0 & & $\mid 1876 \cdot 4$ & & $1873 \cdot 9$ & $\mid \cdots$. & .1876 .0 \\
\hline Yockenthwaite Moor & $2112 \cdot 3$ & & $2110 \cdot 9$ & $2112 \cdot 0$ & $2110 \cdot 4$ & & $2111 \cdot 4$ \\
\hline Stake Fell .... & $1843 \cdot 4$ & & $1842 \cdot 9$ & $1844 \cdot 0$ & 1842.5 & & $.1843 \cdot 2$ \\
\hline brough & 1566.5 & & & & $1563+3$ & & $\cdot 1560 \cdot 1$ \\
\hline & & & - & $1910 \%$ & ……...... & $\cdots \cdots$ & 15180 \\
\hline 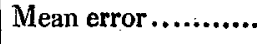 & $-1 \cdot 1$ & & $+1 \cdot 8$ & -0.3 & $0 \cdot 0$ & +2.5 & \\
\hline
\end{tabular}

Reciprocal observations by the four-inch theodolite gave 185.4. feet for the height of Rover Crag above Caldberg Moor, whence we get $\left(1551 \cdot 8-185^{*} 4=\right) 1366^{\circ} 4$ for the altitude of the latter; or $2 \cdot 8$ feet less than by the measurement from Penhill. The height of the Moor, as determined at Settronside $\left(1359^{\circ} 4\right)$ is rejected because the signal could not be satisfactorily identified.

The wall on Whitfield Hill being about $5 \frac{1}{2}$ feet high, we have $1345^{\circ} 4$ feet for the altitude of the ground at the summit.

My next will contain a few barometrical measurements and geological notes made in Wensleydale and the Yorkshire portion of Lunedale.

Leeds, April 2, 1829.

JoHN Nixon.

N. S. Vol. 5. No. 30. June 1829. 3 L $\quad$ LXV. Pro- 